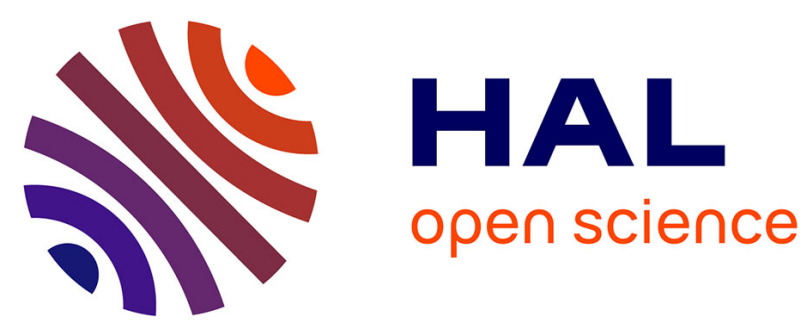

\title{
Resistance of thermally modified ash (Fraxinus excelsior L.) wood under steam pressure against rot fungi, soil-inhabiting micro-organisms and termites
}

Kévin Candelier, Simon Hannouz, Marie-France Thévenon, Daniel Guibal, Philippe Gerardin, Mathieu Pétrissans, Robert Collet

\section{To cite this version:}

Kévin Candelier, Simon Hannouz, Marie-France Thévenon, Daniel Guibal, Philippe Gerardin, et al.. Resistance of thermally modified ash (Fraxinus excelsior L.) wood under steam pressure against rot fungi, soil-inhabiting micro-organisms and termites. European Journal of Wood and Wood Products, 2017, 75 (2), pp.249-262. 10.1007/s00107-016-1126-y · hal-02179527

\section{HAL Id: hal-02179527 \\ https://hal.science/hal-02179527}

Submitted on 10 Jul 2019

HAL is a multi-disciplinary open access archive for the deposit and dissemination of scientific research documents, whether they are published or not. The documents may come from teaching and research institutions in France or abroad, or from public or private research centers.
L'archive ouverte pluridisciplinaire HAL, est destinée au dépôt et à la diffusion de documents scientifiques de niveau recherche, publiés ou non, émanant des établissements d'enseignement et de recherche français ou étrangers, des laboratoires publics ou privés. 


\title{
Resistance of thermally modified ash (Fraxinus excelsior L.) wood under steam pressure against rot fungi, soil-inhabiting micro-organisms and termites
}

\author{
Kévin Candelier $^{1} \cdot$ Simon Hannouz $^{2} \cdot$ Marie-France Thévenon $^{1} \cdot$ Daniel Guibal $^{1}$. \\ Philippe Gérardin ${ }^{3} \cdot$ Mathieu Pétrissans ${ }^{3} \cdot{\text { Robert } \text { Collet }^{2}}^{2}$
}

\begin{abstract}
Thermal modification processes have been developed to increase the biological durability and dimensional stability of wood. The aim of this paper was to study the influence of ThermoWood ${ }^{\circledR}$ treatment intensity on improvement of wood decay resistance against soil-inhabiting micro-organisms, brown/white rots and termite exposures. All of the tests were carried out in the laboratory with two different complementary research materials. The main research material consisted of ash (Fraxinus excelsior L.) wood thermally modified at temperatures of 170, 200, 215 and $228{ }^{\circ} \mathrm{C}$. The reference materials were untreated ash and beech wood for decay resistance tests, untreated ash wood for soil bed tests and untreated ash, beech and pine wood for termite resistance tests. An agar block test was used to determine the resistance to two brown-rot and two white-rot fungi according to CEN/TS 15083-1 directives. Durability against soil-inhabiting micro-organisms was determined following the CEN/TS 15083-2 directives, by measuring the weight loss, modulus of elasticity (MOE) and modulus of rupture (MOR) after incubation periods of 24, 32 and 90 weeks. Finally, Reticulitermes santonensis species was used for determining the termite attack resistance by non-choice screening tests, with a size sample adjustment according to EN 117 standard directives on control samples and on samples which
\end{abstract}

Kévin Candelier

kevin.candelier@cirad.fr

1 CIRAD-Unité de Recherches BioWooEB, TA B 114/16, Montpellier, France

2 LaBoMaP, Arts et Métiers ParisTech, Rue Porte de Paris, 71250 Cluny, France

3 LERMAB, Faculté des Sciences et Technologies, 54506 Vandœuvre-lès-Nancy, France have previously been exposed to soil bed test. Thermal modification increased the biological durability of all samples. However, high thermal modification temperature above $215^{\circ} \mathrm{C}$, represented by a wood mass loss (ML\%) due to thermal degradation of $20 \%$, was needed to reach resistance against decay comparable with the durability classes of "durable" or "very durable" in the soil bed test. The brown-rot and white-rot tests gave slightly better durability classes than the soil bed test. Whatever the heat treatment conditions are, thermally modified ash wood was not efficient against termite attack neither before nor after soft rot degradation.

\section{Introduction}

Heat treatment consists of a wood pyrolysis torrefaction performed in a very poor oxygen atmosphere to avoid wood combustion. The environmental impact of this process is low, heat is introduced in the treatment system and smoke from wood thermal degradation can be retrieved, condensed and purified (Pétrissans et al. 2007). At its end of life cycle, heat-treated wood can be recycled without detrimental impact on the environment, contrary to some chemically impregnated wood containing biocidal active ingredients (CRIQ 2003). Although several processes (e.g. Plato-Process, Bois Perdure, OHT-Process, ThermoWood Process, etc.) exist due to conditions used for heat conduction (Hannouz 2014), the basic concept is common, that is to modify wood chemical structure at a defined temperature in inert atmosphere (Militz 2002). There are plenty of end-uses for thermally modified timber in many different applications, such as exterior cladding, covered decking, flooring, garden furniture, paneling, kitchen furnishing, and bathroom decor. 
Thermal modification of wood, using soft pyrolysis at heating temperature ranging from 180 to $280{ }^{\circ} \mathrm{C}$, is an attractive environmentally acceptable treatment to protect wood material against moisture content (MC) variations (Hill 2006; Pétrissans et al. 2003) and Basidiomycetes degradation (Tjeerdsma et al. 2000), to improve dimensional stability (Korkut et al. 2012), and increase the dark coloration of wood (Chen et al. 2012). Therefore, heat treatment allows to use low durability timber by making it resistant against decay for end-use in use class 2 and 3.1 [use class 3.2 has to be checked by field tests (Welzbacher and Rapp 2007), and use class 4 being excluded due to the occurrence of soft rots and termite degradation] (EN 335, 2013b) and with high economic value (Allegretti et al. 2012; Kamdem et al. 2002). These upgraded biological properties conferred to the wood are the result of chemical modifications of wood cell wall polymers occurring during treatment (Inari et al. 2007). However, the surface hardness of the heat treated wood can be improved for several wood species thermally modified at treatment temperature lower than $210^{\circ} \mathrm{C}$ (Sivrikaya et al. 2015a). Low temperature and time cause the increase in the hardness value while high temperature and time decrease the hardness value of heattreated wood (Lekounougou and Kocaefe 2014), due to higher degradation of hemicellulose and cellulose and evaporation of extractive compounds (Karamanoğlu and Aky1ldız 2013; Esteves and Pereira 2009). These last improvements have an adverse effect on wood mechanical properties such as bending and compression strength, stiffness and shear strength (Dilik and Hiziroglu 2012; Candelier et al. 2013; Hannouz et al. 2015, Hermoso et al. 2015). The improved fungal resistance of thermally modified wood has also been reported by Viitanen et al. (1994), Sailer et al. (2000), Hakkou et al. (2006), Welzbacher and Rapp (2007), Mburu et al. (2006) and Boonstra et al. (2007). Sivonen et al. (2003) studied the chemical properties of thermally modified Scots pine exposed to brown and soft-rot fungi and found that, as with the untreated wood, brown-rot fungi degraded mainly hemicelluloses, while soft-rot fungus attacked cellulose more extensively. Weight loss caused by fungal attack was dependent on the thermal modification temperature and duration. Previous studies, mainly achieved at laboratory scale, have proven high correlations between mass loss issued from wood thermal degradation (ML\%), treatment intensity (time and temperature) and weight loss (WL\%) of heat-treated wood due to fungal decay (Hakkou et al. 2006; Chaouch et al. 2013; Candelier et al. 2016). Weiland and Guyonnet (2003) also found that in spite of strong hemicellulose degradation by thermal modification, the fungal attack still takes place. In addition, the degradation of wood components caused by decaying fungi decreases the mechanical properties of wood (Curling et al. 2002; Metsä-Kortelainen and Viitanen 2010, Råberg et al. 2012).

The impact of thermal treatment on wood termite resistance has also already been studied. However, it appears that the termite resistance of heat treated wood was impacted in a random way, was indiscriminate and even reduced in many cases, according to modification process conditions. Momohara et al. (2003) worked on Japanese cedar (Cryptomeria japonica D. Don) drying under saturated steam at different temperatures (from 60 to $150{ }^{\circ} \mathrm{C}$ ) and with several treatment durations (from 6 to $72 \mathrm{~h}$ ). They highlighted that Japanese cedar wood samples treated at higher temperatures $\left(135-150{ }^{\circ} \mathrm{C}\right)$ showed larger weight loss due to termite attack than those treated at lower temperatures $\left(60{ }^{\circ} \mathrm{C}\right)$. They observed significant differences between 135 or $60{ }^{\circ} \mathrm{C}$ and $150{ }^{\circ} \mathrm{C}$. In the case of Japanese larch heartwood, steam treatment was also reported to increase termite attraction (Doi et al. 1998). For severe treatment temperature, Salman et al. (2016) found that Scots pine sapwood (Pinus sylvestris L.) treated at $220{ }^{\circ} \mathrm{C}$ for $20 \mathrm{~h}$, submitted to termite attack after or without leaching, was equally degraded compared to untreated wood, although the termite mortality rate was higher for treated wood samples. On the other side, Nunes et al. (2004) studied the resistance of wood heat-treated by hot oil bath (OHT) to the termite Reticulitermes grassei and concluded that despite the slightly higher mortality of termites in treated samples and smaller mass loss, the difference was not significant. However, when treated and untreated counterpart wood samples were side by side during exposure, termites preferred untreated wood. These last results (Nunes et al. 2004) could be justified by the addition of oil into the wood during the thermal modification process. However, in such a treatment, the oil is sufficient to make the wood treated with it more hydrophobic, making it more resistant to the attack of fungi and termite. In another study, more similar to this present work, Sivrikaya et al. (2015b) studied the impact of Thermowood $^{\circledR}$ process on Reticulitermes grassei termite resistance of different wood species and showed that such a heat treatment did not enhance the termite resistance of ash wood; the survival rate of the termite workers gradually increased irrespective of the increase in temperature, and that to a similar extent to the samples degradations.

The aim of this study was to measure the impact of Ther$\operatorname{moWood}^{\circledR}$ process conditions (treatment intensity) on the thermal degradation kinetic of ash wood and on its conferred durability against brown rot, white rot and during unsterile soil bed exposure. Finally, resistance to termite tests have been performed on ash wood control samples, beech wood control samples and heat-treated ash wood samples which have been submitted to soil bed tests beforehand. 


\section{Materials and methods}

\subsection{Wood samples}

Industrially kiln-dried heartwood planks of ash wood (Fraxinus excelsior L.) were selected from a French company of Wood thermal modification (Bois Durables de Bourgogne, 71120 Vendenesse-lès-charolles, France). For the laboratory thermal modification operations, 20 planks $\left[4000 \times 25 \times 110 \mathrm{~mm}^{3}(\mathrm{~L} \times \mathrm{R} \times \mathrm{T})\right]$ of test material, with only small variations in density $\left(650 \mathrm{~kg} / \mathrm{m}^{3} \pm 10 \%\right)$ and widths of annual rings, were selected. The planks were selected so that they do not include heartwood. All planks were split down the middle and cut into two $2 \mathrm{~m}$-long pieces. One half of the planks were left as reference material and the other half was thermally modified.

\subsection{Heat treatment protocols}

The ThermoWood ${ }^{\circledR}$ method (Finnish Thermowood Association 2003) was used in all the thermal modification operations, by the French company Bois Durables de Bourgogne $^{\circledR}$. The temperature inside the wood and the atmosphere in the kiln were measured during the processes. The thermal modification operations were controlled by these measured temperatures (Fig. 1). The thermal modification duration, at the targeted temperature, was $2 \mathrm{~h}$ for every test run while the thermal modification temperature was varied from 170 to $228^{\circ} \mathrm{C}$. Four ash wood planks were treated for each temperature.

Each heat treatment was carried out simultaneously on boards of $2000 \times 25 \times 110 \mathrm{~mm}^{3}(\mathrm{~L} \times \mathrm{R} \times \mathrm{T})$. Thermal treatment was performed in a $20 \mathrm{~m}^{3}$ industrial oven by convection under steam pressure. The oven temperature was slowly increased by $0.5{ }^{\circ} \mathrm{C} \mathrm{min}^{-1}$ from ambient to $103{ }^{\circ} \mathrm{C}$ to dry each wood board during $48 \mathrm{~h}$ and to obtain

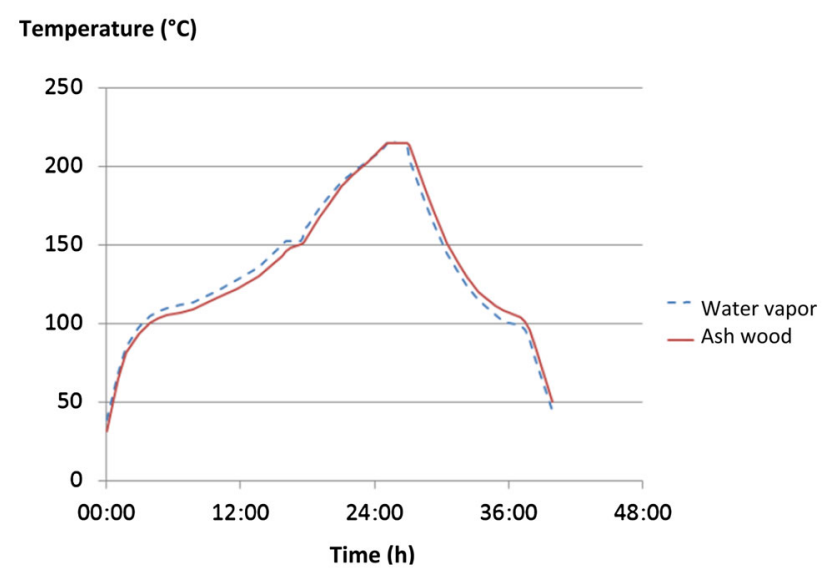

Fig. 1 Temperature kinetics of ash wood and water vapor during heat treatment performed at $210{ }^{\circ} \mathrm{C}$ for $2 \mathrm{~h}$ their anhydrous weight $\left(\mathrm{m}_{0}\right)$. After this period, the plate's temperature was increased by about $0.2{ }^{\circ} \mathrm{C} \mathrm{min}^{-1}$ from 103 to $150^{\circ} \mathrm{C}$ and the temperature was maintained for $1 \mathrm{~h}$. The temperature was then increased by about $0.2{ }^{\circ} \mathrm{C} \min ^{-1}$ from $150{ }^{\circ} \mathrm{C}$ to the targeted temperature to perform wood thermal modification. The heating system was then stopped and wood samples were cooled down to room temperature under an oxygen free atmosphere.

\subsection{Mass loss (ML) due to wood thermal degradation}

Anhydrous mass measurements were performed on each ash wood plank before $\left(\mathrm{m}_{0}\right)$ and after thermal modification $\left(\mathrm{m}_{1}\right)$ in order to determine the mass loss (ML\%) due to thermal degradation depending on treatment conditions.

$\operatorname{ML}(\%)=\left(\mathrm{m}_{0}-\mathrm{m}_{1}\right) / \mathrm{m}_{0}$.

\subsection{Decay resistance tests}

According to an adaptation of XP CEN/TS 15083-1 (2006) standard criteria, 20 blocks of $25 \times 10 \times 5 \mathrm{~mm}^{3}$ in longitudinal, radial and tangential direction were cut from untreated and from each heat-treated wood modality, and dried at $103{ }^{\circ} \mathrm{C}$ for $48 \mathrm{~h}\left(\mathrm{~m}_{2}\right)$. Petri dishes $(90 \mathrm{~mm}$ diameter) were filled with sterile culture medium prepared by mixing $40 \mathrm{~g}$ malt and $20 \mathrm{~g}$ agar in $1 \mathrm{~L}$ of distilled water, inoculated with the different fungi and incubated at $22{ }^{\circ} \mathrm{C}$ and $70 \%$ relative humidity to allow full colonization of the surface by the mycelium. Decay resistance was tested on both fungi species required by the standard: Coriolus versicolor Quélet (CV) [Linnaeus, CTB 863 A] and Coniophora puteana Karsten (CP) [Schumacher ex Fries, Bam Ebw. 15], and on two other non-obligatory fungi species Gloeophyllum trabeum Murill (GT) [Persoon ex Fries, BAM Ebw. 109], and Poria placenta Coocke sensu J. Erikson (PP) [Fries, FPRL 280]. Three blocks (2 treated and one untreated ash wood sample as control) were placed in each Petri dish and incubated during 12 weeks to evaluate the effect of thermal modification (Fig. 2). For each fungus, nine untreated beech (Fagus sylvatica L.) wood samples were distributed into three Petri dishes and subjected to the decay resistance tests to assess the virulence of the fungi. Each experiment was triplicated. After this period, mycelia were removed and the blocks were dried at $103{ }^{\circ} \mathrm{C}$ and weighed $\left(\mathrm{m}_{3}\right)$ to determine the weight loss (WL) caused by the fungal attack.

$\mathrm{WL}(\%)=\left(\mathrm{m}_{2}-\mathrm{m}_{3}\right) / \mathrm{m}_{2}$.

Weight loss was calculated and expressed as a percentage of their initial values. The results of the decay resistance test were classified into durability classes based 


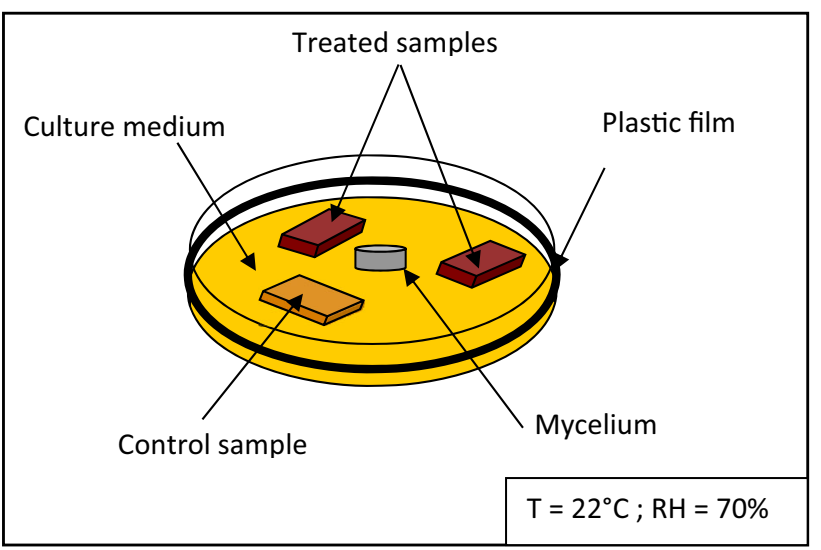

Fig. 2 Screening decay resistance tests according to Bravery and Dickinson (1979) (with some adjustments in size, number of samples and incubation duration)

Table 1 Durability rating scale according to XP CEN/TS 15083-1 (2006)

\begin{tabular}{lll}
\hline Durability class & Description & Percent loss in mass \\
\hline 1 & Very durable & $\leq 5$ \\
2 & Durable & $>5$ to $\leq 10$ \\
3 & Moderately durable & $>10$ to $\leq 15$ \\
4 & Slightly durable & $>15$ to $\leq 30$ \\
5 & Not durable & $>30$ \\
\hline
\end{tabular}

on the Weight Losses range, according to the criteria of XP CEN/TS 15083-1 (2006) (the criteria being adjusted to the sample size and the numbers of the tested samples). The estimated durability classes are shown in Table 1.

\subsection{Soil bed tests}

The natural durability against unsterile soil rot micro fungi of untreated and thermally modified ash wood was determined according to the directives of XP CEN/TS 15083-2 (2006) with adjustments concerning the number of the tested samples and incubation room conditions. Small specimens $\left(100 \times 10 \times 5 \mathrm{~mm}^{3}\right)$, issued from treated and untreated woods, were inserted into containers with unsterile soil composed of around $80 \%$ of commercial compost (Géolia ${ }^{\circledR}$-Universal Compost) and $20 \%$ of natural soil from Cluny-France $\left(46^{\circ} 26^{\prime} 04^{\prime \prime} \mathrm{N} ; 4^{\circ} 39^{\prime} 33^{\prime \prime} \mathrm{E}\right)$. PH$\mathrm{H}_{2} \mathrm{O}$ [1:2], determined according to NF ISO 10390 (2005) was 6.6. Water holding capacity (WHC) of the soil used for these tests, determined according to XP CEN/TS 15083-2 (2006) was $45 \%$. The incubation times were 24,32 and 90 weeks at $20{ }^{\circ} \mathrm{C}$ and $65 \%$ relative humidity. Each week, an amount of water was added into the containers to preserve the soil humidity.
Ten specimens from each wood material were used for each incubation duration. All samples were conditioned at $103{ }^{\circ} \mathrm{C}$ and weighed before $\left(\mathrm{m}_{4}\right)$ and after $\left(\mathrm{m}_{5}\right)$ unsterile soil incubation period in order to determine their anhydrous masses and weight losses due to soil degradation agents $\left(\mathrm{WL}_{\mathrm{sbt}} \%\right)$.

$\mathrm{WL}_{\mathrm{sbt}}(\%)=\left(\mathrm{m}_{5}-\mathrm{m}_{4}\right) / \mathrm{m}_{4}$.

Ten untreated beech (Fagus sylvatica L.) wood samples were placed in the soil bed for each tested time exposure (24, 32 and 90 weeks) in order to assess the virulence of degradation of the soil.

In order to evaluate the effect of soil degradation agents on untreated and treated ash wood, three-point bending tests (MOE, MOR) were carried out on each sample. Mass loss and mechanical loss results were then compared. An INSTRON 4467 Universal Mechanical Testing Machine was used for the measurements. After having measured anhydrous mass of the samples after unsterile soil exposure, samples were conditioned in a room with $65 \pm 5 \%$ $\mathrm{RH}$ and $20 \pm 2{ }^{\circ} \mathrm{C}$ for the time necessary to stabilize until constant weight. Three point static bending tests were carried out according to EN 408 (2012). The moving head speed and the span length were $1 \mathrm{~mm} \mathrm{~s}^{-1}$ and $90 \mathrm{~mm}$, respectively. The load deformation data obtained were analyzed to determine the modulus of elasticity (MOE) and the modulus of rupture (MOR). Tests were replicated six times for each treatment and exposure conditions.

Weight loss and MOE loss were calculated and expressed as a percentage of their initial values. The results of the soft-rot test were classified into durability classes based on the calculated $\mathrm{X}$ value, with:

$X_{\text {Value }}=$

$$
\frac{\text { Median value of } \mathrm{WL}_{\mathrm{sb}} \text { for test wood specimens }}{\text { Median value of } \mathrm{WL}_{\mathrm{sbt}} \text { for reference wood specimens (beech) }}
$$

The durability classes are shown in Table 2 .

\subsection{Termite tests}

Treated and untreated ash wood samples $\left(25 \times 10 \times 5 \mathrm{~mm}^{3}-\mathrm{L}, \mathrm{R}, \mathrm{T}\right)$ previously submitted or not

Table 2 Durability rating scale according to XP CEN/TS 15083-2 (2006)

\begin{tabular}{lll}
\hline Durability class & Description & Percent loss in mass \\
\hline 1 & Very durable & $\leq 0.10$ \\
2 & Durable & $>0.10$ to $\leq 0.20$ \\
3 & Moderately durable & $>0.20$ to $\leq 0.45$ \\
4 & Slightly durable & $>0.45$ to $\leq 0.80$ \\
5 & Not durable & $>0.80$ \\
\hline
\end{tabular}




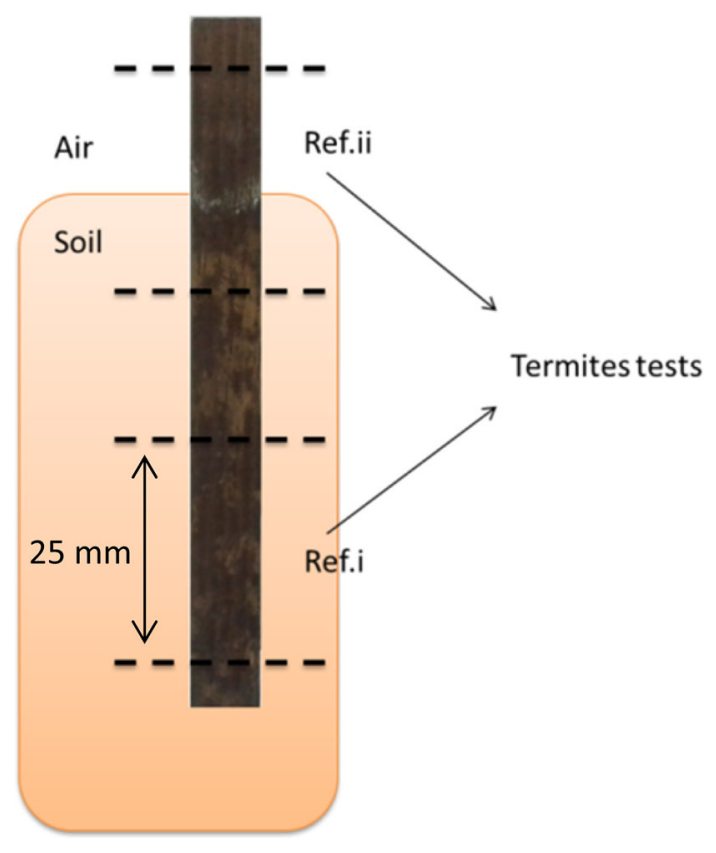

Fig. 3 Heat treated wood degraded by soil-inhabiting micro-organisms sampling to test against termite attacks to soft rot attacks were exposed to termites (Reticulitermes santonensis) in non-choice screening tests. Beech and pine wood have also been tested against termites exposure as reference. Prior to being tested against termites, each sample issued from soil bed tests has been cut into two parts (Fig. 3): soil exposure (ref. i) and air/soil exposure (ref. ii).

Each specimen was placed in the middle of a Petri dish (90 mm diameter) filled with wet sand. 50 termite workers were collected and placed with each tested sample. These specimens were kept at $27{ }^{\circ} \mathrm{C}$ and $>75 \%$ relative humidity for 4 weeks (Fig. 4). Observations were carried out on a weekly basis in order to add water and check termite behavior. At the end of the test, termite survivors were counted, tested sample degradation was given a visual rating according to the criteria of EN 117 (2013a) (the criteria being adjusted to the sample size) and the weight loss $\left(\mathrm{WL}_{\mathrm{term}} \%\right.$ ) was measured by difference between anhydrous masses before and after the termite exposure.

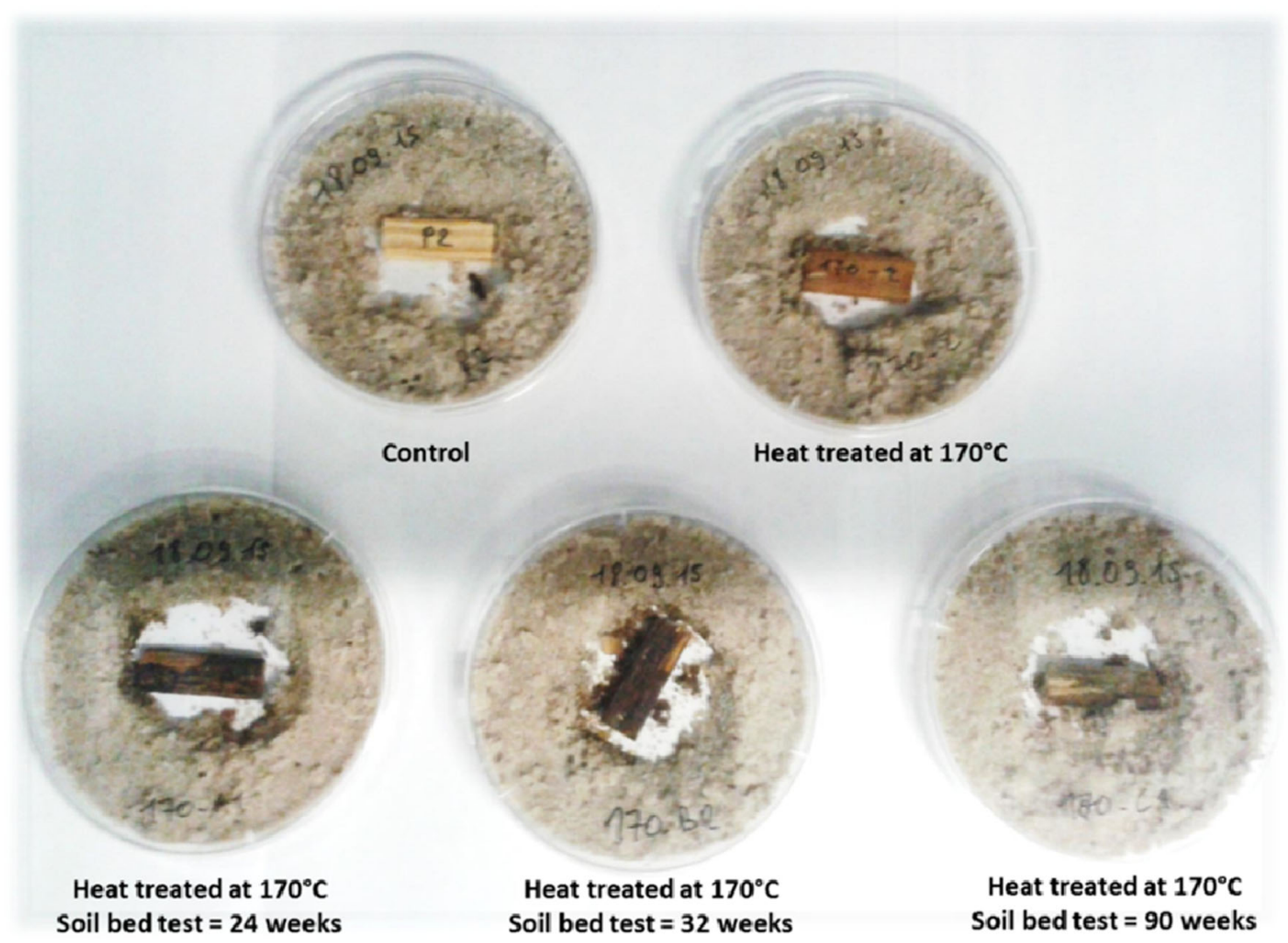

Fig. 4 Screening termites test devices, with adjustments to EN 117 standard guidelines, for control and heat-treated ash wood previously degraded by soil-inhabiting micro-organisms (Ref.i) at different incubation durations 


\subsection{Statistical analysis}

Statistical analyses (one-way analysis of variance) using Fisher test and the JMP 10.0.2 program (SAS Institute Inc., Cary, NC, USA) have been performed. The effects of treatment intensity on mass loss, weight loss due to fungal attack, weight loss due to soil-inhabiting microorganisms, mechanical properties and termite resistance before and after soil bed tests were evaluated using ANOVA and Duncan's comparison test. Such analysis allows to class results into several categories from "a" to "g". Systems which are not connected by the same letter are largely different at the $5 \%$ level.

\section{Results and discussion}

\subsection{Mass loss (ML) due to wood thermal degradation}

Results of mass loss due to thermal degradation of wood are given in Table 3. According to literature (Candelier et al. 2011; Tenorio and Moya 2013), thermal degradation kinetics of wood, often characterized by mass loss (ML\%), is mainly influenced by treatment temperature (Stamm 1956). Indeed, concerning heat treatment performed on ash wood during $2 \mathrm{~h}$ at $170,200,215$ and $228{ }^{\circ} \mathrm{C}$, mass loss of $11,16,20$ and $25 \%$ was obtained, respectively.

Similar results have been found by Chaouch et al. (2010) in a study on the correlation between mass loss and treatment intensity (time and temperature) during the heat treatment of several wood species such as silver fir, pine, beech, poplar and ash. It is reported that wood thermal degradation kinetics strongly depends on the nature of hemicelluloses initially present in wood. In fact, acetic acid liberated during thermal degradation of hemicellulose catalyzes the thermal chemical reactions of wood degradation. This acetic acid production strongly depends on the nature of the wood species: hardwoods lead to higher amounts of acid compared to softwoods. The higher susceptibility of hardwoods to thermal degradation compared to softwoods, has thus been attributed to their higher content in acetyl groups (Sjöström 1981, Fengel and Wegener 1989) from acetylated glucoronoxylan, leading to the formation of a considerable amount of acetic acid involved in hemicelluloses and lignin degradation (Candelier et al. 2011).

\subsection{Decay resistance tests}

For each tested rot, similar results have been found. However, Poria placenta was the most aggressive rot on beech control samples (WL 49.9\%), whereas Coriolus

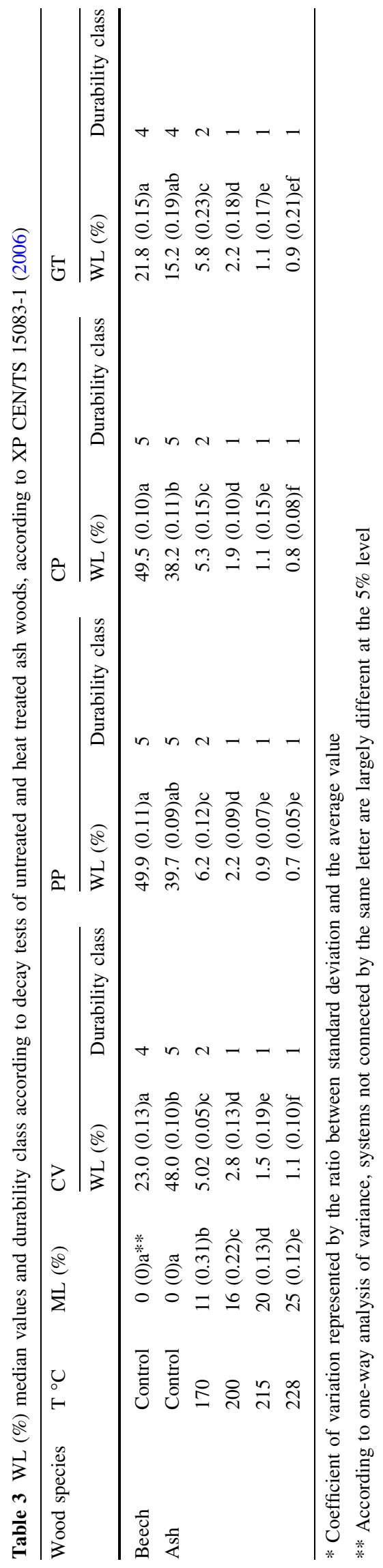


versicolor was the most degrading rot on ash control samples (WL 48\%). Except for ash wood heat-treated at $170{ }^{\circ} \mathrm{C}$ where Poria placenta was the most aggressive rot (WL 6.2\%), Coriolus versicolor was the most degrading rot for control and other differently modified ash wood samples. Mass losses caused by Coriolus versicolor on ash wood treated at 200,215 and $228{ }^{\circ} \mathrm{C}$ were $2.8,1.5$ and $1.1 \%$, respectively. The thermal modification increased the durability of all wood materials, which is in agreement with previous studies (Kamdem et al. 2002; Esteves and Pereira 2009). These results were expected as Rousset et al. (2004) and Metsä-Kortelainen et al. (2005) also found that the thermal treatment of wood at high temperatures increases the decay resistance of wood. Moreover, Momohara et al. (2003) showed that an increase in duration and temperature during thermal treatment increased the decay resistance of wood, which is in line with the current results. Yalcin and Sahin (2015) studied the decay resistance improvement of narrow-leaved ash wood after thermal treatment under saturated steam and different treatment intensity (temperature range from 140 to $220{ }^{\circ} \mathrm{C}$ and for duration ranging between 2 and $6 \mathrm{~h}$ ). They also found no significant change in the weight loss caused by fungi up to a treatment temperature of $180{ }^{\circ} \mathrm{C}$, but they observed a significant decrease at higher temperatures. The decay resistance of thermally modified narrow-leaved ash increased with increasing duration of heat treatment at higher temperatures. These authors have also correlated the decrease of the weight loss due to fungal attack with the decrease in equilibrium moisture content of the wood and with the changes in the chemical composition of heattreated wood.

It can be seen in Table 3 that Coriolus versicolor (CV), Poria placenta (PP) and Coniophora puteana (CP) inflicted greater damages to ash control samples compared to degradation due to Gloeophyllum trabeum (GT). While after thermal modification, weight loss due to the fungal attack of heat-treated ash wood, with the same treatment intensity, becomes similar whatever the rot fungi.

In most studies, an average mass loss (ML\%) due to thermal degradation of $12 \%$ confers to heat-treated wood durability class 3 according to the specifications of EN 350-1 (1994) (Welzbacher and Rapp 2002; Kamdem et al. 2002; Chaouch et al. 2010; Elaieb et al. 2015). Although these authors did not use the same test method (EN 350-1, 1994) as that used in this work (XP CEN/TS 15083-1, 2006), they confirmed that a level of heat-treated wood ML higher than $12 \%$ makes it a significantly more durable material than respective untreated wood.

In this study, such a mass loss of $12 \%$ was reached by a thermal treatment performed at $200{ }^{\circ} \mathrm{C}$ (Table 3). According to Table 3, thermal treatment performed at higher temperatures than $200{ }^{\circ} \mathrm{C}$ conferred to the heat- treated wood material durability class 1 "very durable", according to the classification method of XP CEN/TS 15083-1 (2006).

This concurs with results from Paul et al. (2006) and Mazela et al. (2004), who reported limited improvement of resistance to fungal decay for heat treatment temperatures below $200^{\circ} \mathrm{C}$. A minimum heat-treatment temperature of $220^{\circ} \mathrm{C}$ for a sufficient increase in the resistance to fungal decay is also recommended by Jämsä and Viitaniemi (2001), Welzbacher et al. (2007), Šušteršic et al. 2010) and Syrjänen and Kangas (2000), which also points to the significant impact of the treatment temperature on the resulting treatment intensity (Candelier et al. 2011).

\subsection{Soil bed tests}

Visual checking, measurements of weight loss, MOE and MOR were performed after 24, 32 and 90 weeks of exposure. The results of the unsterile soil bed test, integrating tests soil-inhabiting microorganisms degradations, highlighted a significant improvement in relative durability of all heat-treated materials compared with ash wood controls.

\subsubsection{Visual appearance}

According to the visual appearance of wood samples after soil bed tests (Fig. 5), it can be deducted that the soil contained mainly white rots which degrade mainly the lignin component, without causing twist stress to the wood sample (Talaei et al. 2013). Figure 5 clearly shows the influence of thermal treatment temperature on decay resistance of soil-inhabiting micro-organisms on heattreated ash wood, according to the visual appearance of each wood sample.

\subsubsection{Weight loss due to soil bed tests}

As shown in Fig. 6, the degree of the value of weight loss $\left(\mathrm{WL}_{\mathrm{sbt}}\right)$ increased as a function of the exposure time to soil-inhabiting micro-organisms, whatever the wood species used as reference and the thermal treatment intensity used on thermally modified ash wood. Nevertheless, as for the resistance to fungal attack, it appears that the wood weight loss due to soil exposure is considerably reduced by thermal treatment carried out on ash wood at temperatures above $200{ }^{\circ} \mathrm{C}$.

From treatment temperature of $215^{\circ} \mathrm{C}$, Thermowood ${ }^{\circledR}$ process allows to classify modified ash wood as a "very durable" material (Table 4) according to XP CEN/TS 15083-2 (2006) (the adjusted criteria are specified in part 2.5) (Table 2). Metsä-Kortelainen and Viitaniemi (2009) 


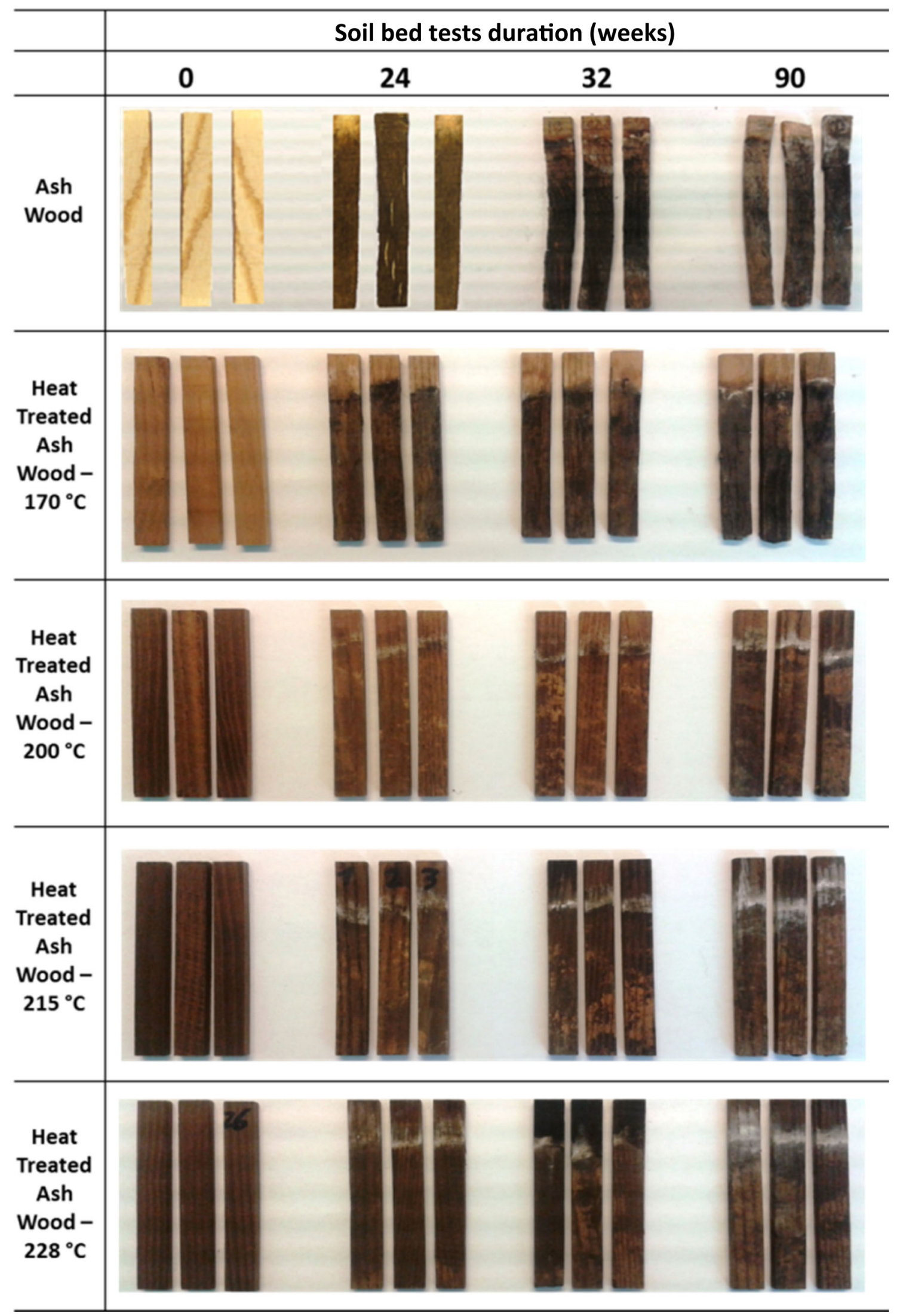

Fig. 5 Visual appearance of untreated and heat-treated ash wood after unsterile soil exposure at different durations 


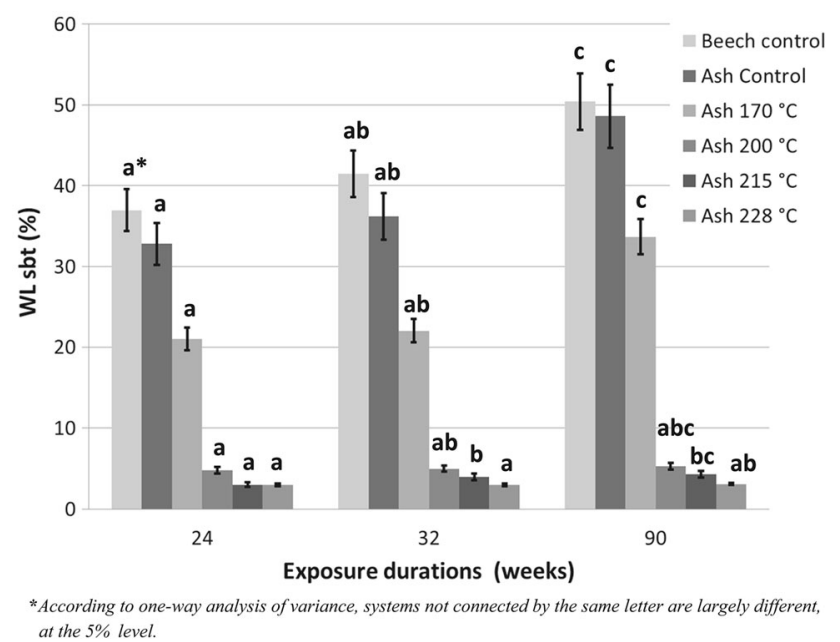

Fig. 6 Weight loss $\left(\mathrm{WL}_{\mathrm{sbt}} \%\right)$ due to unsterile soil exposure of untreated and heat-treated ash wood and beech wood reference

also found that pine sapwood and heartwood, thermally treated at a temperature of $230{ }^{\circ} \mathrm{C}$ and brought into unsterile soil for 32 weeks reached the classes "moderately durable" and "very durable" according to the weight and MOE loss differences, respectively.

\subsubsection{Mechanical loss after soil bed test degradation}

As previously reported in literature (Kim et al. 1998; Bal 2014), it was observed (Fig. 7) that the mechanical resistance of heat-treated ash wood, MOE and MOR in bending, decreased according to the treatment temperature. According to previous studies, it appears that weight loss greater than $10 \%$ for bio-deteriorated samples exposed to soil-inhabiting micro-organisms results in significant damages to mechanical properties (Curling et al. 2002; Venäläinen et al. 2014). Edlund and Jermer (2004) concluded that the high rate of failure was a possible consequence of the strength loss caused by the thermal modification, enhanced by wetting in the ground and further chemical degradation. In general, there was a similar trend in the mass and modulus of (a)

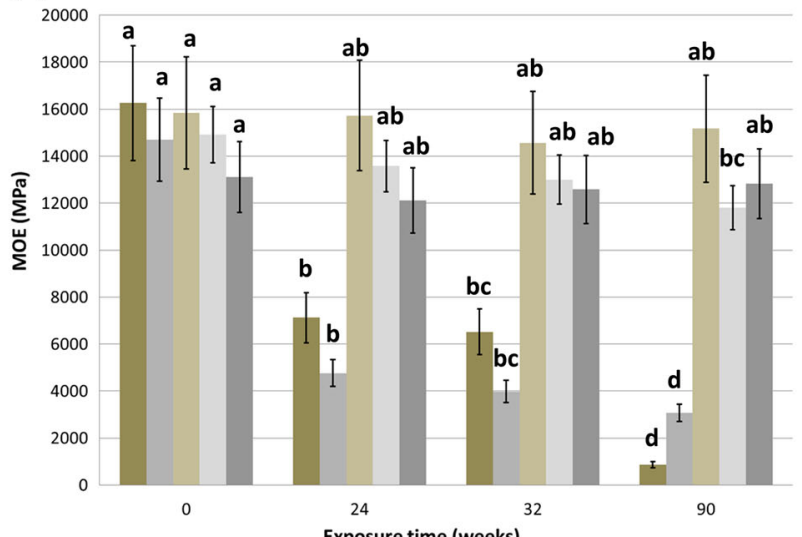

(b)

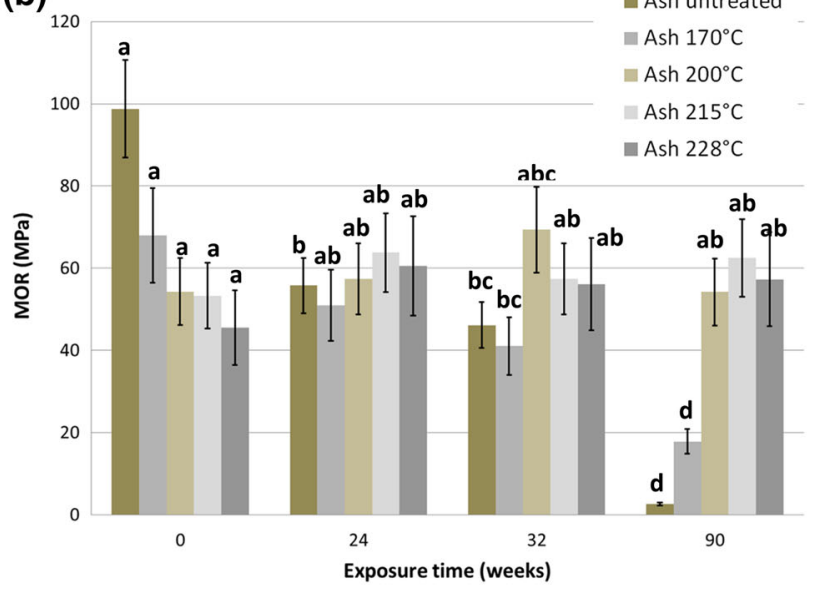

*According to one-way analysis of variance, systems not connected by the same letter are largely different, at the $5 \%$ level.

Fig. 7 Mechanical properties [MOE (a), MOR (b)] of untreated and heat-treated ash wood after unsterile soil exposure

elasticity (MOE) loss values, and the correlation between these values was very high. The weight and MOE loss values were much greater than the MOR values, which indicate that MOE is a more sensitive measure for detecting fungal attack in the wood. This is in agreement with Humar et al. (2006) and Temiz and Yildiz (2006).

Table $4 \mathrm{X}^{*}$ values and Durability Class according to soil bed tests of untreated and heat treated ash woods

\begin{tabular}{|c|c|c|c|c|c|c|c|}
\hline \multirow[t]{3}{*}{ Wood species } & \multirow[t]{3}{*}{$\mathrm{T}^{\circ} \mathrm{C}$} & \multicolumn{6}{|c|}{ Soil bed tests exposure duration } \\
\hline & & \multicolumn{2}{|l|}{24 weeks } & \multicolumn{2}{|l|}{32 weeks } & \multicolumn{2}{|l|}{90 weeks } \\
\hline & & $\mathrm{X}$ values* & Durability class & $\mathrm{X}$ values* & Durability class & $\mathrm{X}$ values* & Durability class \\
\hline \multirow[t]{5}{*}{ Ash } & Control & 0.89 & 5 & 0.87 & 5 & 0.94 & 5 \\
\hline & 170 & 0.57 & 4 & 0.53 & 4 & 0.67 & 4 \\
\hline & 200 & 0.13 & 2 & 0.12 & 2 & 0.11 & 2 \\
\hline & 215 & 0.08 & 1 & 0.10 & 1 & 0.09 & 1 \\
\hline & 228 & 0.08 & 1 & 0.07 & 1 & 0.06 & 1 \\
\hline
\end{tabular}

* $X$ median value of $\mathrm{WL}_{\mathrm{sbt}}$ for test wood specimens/median value of $\mathrm{WL}_{\mathrm{sbt}}$ for reference wood specimens (beech) 
Concerning heat treatments performed on ash wood at temperatures above $200{ }^{\circ} \mathrm{C}$, it appeared that the soil bed test duration of 24 weeks could be sufficient to estimate the resistance of modified wood. In fact, for longer exposure times ( 32 and 90 weeks), ash wood heat-treated at $215^{\circ}$ and $228{ }^{\circ} \mathrm{C}$ does not seem to be more degraded. On the contrary, wood heat-treated at temperatures below $200{ }^{\circ} \mathrm{C}$ continues to be degraded after 24 weeks of soil incubation. For these treatment intensities, soil bed test should be prolonged because the modified wood continues to deteriorate significantly after 24 and 32 weeks of incubation (Junga and Militz 2005; Kamdem et al. (2002).

For each treatment intensity and for all exposure durations to soil bed test, MOR of heat-treated ash wood seems to be very slightly affected by soil-inhabiting micro-organisms. In fact, standard deviations results from MOR determination do not allow evaluating the impact of thermal treatment intensity on decay resistance of unsterile soil. Even if a small MOR increase for decayed heat-treated ash wood can be observed, which could be due to a surface densification of the wood material due to its contact with the soil during the soil bed test.

\subsection{Termite resistance after unsterile soil bed test}

With control, mortality of termites was less than $50 \%$ and the degree of attack was 4 , which allows to validate the test.

\subsubsection{Effect of heat treatment without unsterile soil incubation on termite resistance}

The survival of termites reveals an effect on termite biology. Although survival rate was similar for treatments at 170 and $200{ }^{\circ} \mathrm{C}$, it was lower above these temperatures (Table 5). Heat treatments performed at higher temperature than $200{ }^{\circ} \mathrm{C}$ cause critical changes to the wood and consequently its durability can be improved. Since wood is still degraded, a toxicity of eaten components may explain the increase in the termite mortality rate (Surini et al. 2012) according to the increase of heat treatment intensity. However, it is not totally efficient on a short time scale, as $51.33 \%$ of the termites were still alive after the test, with no significant differences between treated and untreated wood. The current results are in agreement with those of Nunes et al. (2004), who studied the resistance to termites of the species Reticulitermes grassei with wood treated by the German method (OHT) and concluded that in spite of the slightly higher mortality of termites in treated samples and smaller weight loss, the differences were not significant.

\subsubsection{Effect of heat treatment on termite resistance after unsterile soil exposures}

According to the visual appearance of wood samples after soil bed tests (Fig. 5), it can be deducted that the soil contained mainly white rots (Talaei et al. 2013). The termites with their cellulose decomposing bacteria in the gut can easily degrade and digest the cellulose of wood (Stamm 1964; Akio et al. 1990). The cellulose is the woody polymer which has been the less degraded by the heat treatment and by soil-inhabiting micro-organisms. Heattreated ash wood previously subjected to soil bed tests remains vulnerable to termite attack (Table 5).

3.4.2.1 Soil exposure (ref. $i$ ) The exposure of treated ash wood, after soil bed test, to termite colonies showed a lower resistance to termite attack than those of the untreated samples, whatever the previous exposure duration to soil-inhabiting micro-organisms was. However, it was observed that weight losses due to termite attack stabilized (decreased slightly) after 32 weeks of soil incubation for each treatment intensity.

3.4.2.2 Air/soil exposure (ref. ii) The exposure of ash wood treated at $170{ }^{\circ} \mathrm{C}$, after soil bed test with air contact, to termite colonies showed a lower resistance to termite attack than that of the untreated samples, whatever the previous exposure duration to soil-inhabiting micro-organisms. For thermal treatments performed at higher temperature (from 200 to $228^{\circ} \mathrm{C}$ ), termite resistance was improved whatever the exposure duration to soil-inhabiting micro-organisms was. However, it appears that for each treatment temperature, heat-treated ash wood incubated in the soil during 32 weeks was the most degraded sample by termite attacks, among all tested samples. This result could be explained by the fact that termites prefer rotten wood and that less cellulose is available for termites after 90 than after 32 weeks of exposure to soil-inhabiting microorganisms.

\section{Conclusion}

Heat treatment improves wood durability, increasing clearly the resistance to brown and white rots and moderately the resistance to exposure to soil-inhabiting microorganisms (for the lower treatment intensities), but it has just a little effect on the improvement in termite resistance. The downside of the treatment is the degradation of mechanical properties. The effect on MOE is small, but static bending strength (MOR) is the most weakened property. Several reasons for the improvement of rot resistance have been reported: (1) the transformations of 
Table 5 Average values of mass loss (\%), termite survival rates and visual rating after termite resistance tests

\begin{tabular}{|c|c|c|c|c|c|c|}
\hline $\begin{array}{l}\text { Treatment } \\
\text { temperature }\left({ }^{\circ} \mathrm{C}\right)\end{array}$ & $\begin{array}{l}\text { Soil bed exposure } \\
\text { duration (wks) }\end{array}$ & $\mathrm{WL}_{\text {term }}(\%)$ & $\mathrm{SD}(\%)$ & Survival rate $(\%)$ & $\mathrm{SD}(\%)$ & Visual rating* \\
\hline \multicolumn{7}{|l|}{ Soil (Ref. i) } \\
\hline \multirow[t]{3}{*}{ Control } & Ash & $4.58 f * *$ & 0.57 & 69.67abcd & 8.33 & 4 \\
\hline & Beech & 8.87cde & 1.98 & 69.50abcdef & 13.10 & 4 \\
\hline & Pine & $11.12 c$ & 1.57 & 64.50bcdde & 9.43 & 4 \\
\hline \multirow[t]{4}{*}{170} & Control & $11.80 c d$ & 2.60 & $78.67 a$ & 4.16 & 4 \\
\hline & 24 & $19.44 b$ & 2.84 & 72.00ab & 8.72 & 4 \\
\hline & 32 & $18.96 b$ & 2.16 & $61.33 c d$ & 1.15 & 4 \\
\hline & 90 & $29.11 a$ & 3.46 & $\mathbf{7 0 . 0 0} b$ & 2.83 & 4 \\
\hline \multirow[t]{4}{*}{200} & Control & $11.60 b c d$ & 2.12 & 71.33ab & 6.11 & 4 \\
\hline & 24 & $12.46 c$ & 0.77 & 72.67ab & 3.06 & 4 \\
\hline & 32 & $13.97 b c$ & 3.94 & 72.00ab & 3.46 & 4 \\
\hline & 90 & $13.88 c$ & 1.38 & 72.00ab & 9.17 & 4 \\
\hline \multirow[t]{4}{*}{215} & Control & $10.86 c$ & 1.51 & 56.67de & 5.03 & 4 \\
\hline & 24 & $12.11 c d$ & 3.33 & $\mathbf{5 8 . 0 0} b c d e f$ & 12.49 & 4 \\
\hline & 32 & $14.47 b c$ & 5.21 & 60.67bcde & 9.45 & 4 \\
\hline & 90 & $9.98 c d e$ & 3.13 & 53.33bcdefg & 16.77 & 4 \\
\hline \multirow[t]{4}{*}{228} & Control & $9.23 c d e$ & 1.97 & $\mathbf{5 1 . 3 3} b c d e f g$ & 13.61 & $4(67 \%) ; 3(33 \%)$ \\
\hline & 24 & $10.87 b c$ & 1.18 & $\mathbf{5 2 . 6 7} c d e f$ & 8.08 & 4 \\
\hline & 32 & $14.24 c d e$ & 1.40 & 68.00 $a b c$ & 6.93 & 4 \\
\hline & 90 & $14.12 b c$ & 2.53 & $69.33 a b c$ & 7.57 & 4 \\
\hline \multicolumn{7}{|l|}{ Soil (ref. ii) } \\
\hline \multirow[t]{3}{*}{ Control } & Ash & $4.58 e$ & 0.57 & $69.67 a$ & 8.33 & 4 \\
\hline & Beech & $\mathbf{8 . 8 7} b c d$ & 1.98 & 69.50 $a b$ & 13.10 & 4 \\
\hline & Pine & $\mathbf{1 1 . 1 2} b c$ & 1.57 & 64.50 $a b c$ & 9.43 & 4 \\
\hline \multirow[t]{4}{*}{170} & Control & $11.80 b c$ & 2.60 & 78.67a & 4.16 & 4 \\
\hline & 24 & 23.58 $a$ & 9.06 & $74.00 a$ & 13.11 & 4 \\
\hline & 32 & $18.89 a$ & 2.67 & $69.33 a$ & 1.15 & 4 \\
\hline & 90 & $24.95 a$ & 5.13 & $61.00 a b$ & 4.24 & 4 \\
\hline \multirow[t]{4}{*}{200} & Control & $11.60 b$ & 2.12 & $71.33 a$ & 6.11 & 4 \\
\hline & 24 & $11.50 b$ & 0.89 & 62.67abcd & 10.26 & 4 \\
\hline & 32 & 13.07ab & 3.60 & $72.67 a$ & 4.16 & 4 \\
\hline & 90 & $10.89 a b c d$ & 3.97 & $69.33 a$ & 4.62 & 4 \\
\hline \multirow[t]{4}{*}{215} & Control & $10.86 b$ & 1.51 & $\mathbf{5 6 . 6 7 a b c d}$ & 5.03 & 4 \\
\hline & 24 & $1.92 e d$ & 0.68 & 6.00gh & 6.00 & 2 \\
\hline & 32 & $4.47 d e$ & 2.52 & 22.67efg & 16.17 & $4(67 \%) ; 3(33 \%)$ \\
\hline & 90 & $3.86 e$ & 1.60 & 28.67ef & 11.72 & 3 \\
\hline \multirow[t]{4}{*}{228} & Control & $\mathbf{9 . 2 3} b c d$ & 1.97 & $51.33 a b c d e$ & 13.61 & $4(67 \%) ; 3(33 \%)$ \\
\hline & 24 & $2.43 e$ & 0.35 & $\mathbf{0 . 0 0}$ & 0.00 & $2(67 \%) ; 3(33 \%)$ \\
\hline & 32 & $3.09 e$ & 0.84 & 4.67gh & 4.16 & $2(67 \%) ; 3(33 \%)$ \\
\hline & 90 & 6.79bcdef & 6.54 & 34.00 & 36.17 & 3 \\
\hline
\end{tabular}

* " 0 " for no attack " 1 " for attempted attack, " 2 " for slight attack, "3" for average attack, "4" for a strong attack

** According to one-way analysis of variance, systems not connected by the same letter are largely different at the $5 \%$ level

hemicelluloses, which change from hydrophilic and easily digestible to hydrophobic molecules during heat treatment process; (2) the fungal enzymatic systems do not recognize the substratum and (3) the lower fiber saturation point of heat-treated wood than native wood leads to a better resistance against biological degradation and against changes in the external conditions affecting the microenvironment that affect the decay mechanism of heat-treated 
wood. It is also mentioned that there might be an esterification of cellulose due to acetic acid released by the thermal degradation of hemicelluloses. According to Junga and Militz (2005) and Kamdem et al. (2002), thermally modified wood material is different to untreated wood and it could be necessary to adapt different testing methods to evaluate the final decay resistance of this new material such as a prolonged test exposure (i.e. longer than 16 weeks of exposure) so as to overcome a poor estimation of the durability of the new material. This test adaptation could also be necessary for soil bed test and more particular for heat treatment performed at lower intensities (below $\left.200{ }^{\circ} \mathrm{C}\right)$.

Acknowledgments The authors gratefully acknowledge the company "Bois Durable de Bourgogne" for its financial support through a PhD thesis (Hannouz 2014) in collaboration with the LaBoMaP research laboratory.

\section{References}

Akio E, Hiromi T, Sachiko Y, Goro F (1990) Fungal and termite resistance of etherified wood and its dimensional stability. Kinki Daigaku Nogakubu Kiyo 23:25-32

Allegretti O, Brunetti M, Cuccui I, Ferrari S, Nocetti M, Terziev N (2012) Thermovacuum modification of spruce (Picea abies karst.) and fir (Abies albamill.) wood. BioResources 7:3656-3669

Bal BC (2014) Some physical and mechanical properties of thermally modified juvenile and mature black pine wood. Eur. J. Wood Prod 72:61-66

Boonstra MJ, Van Acker J, Kegel E, Stevens M (2007) Optimisation of a two-stage heat treatment process: durability aspects. Wood Sci Technol 41:31-57

Bravery AF, Dickinson DJ (1979) Screening techniques for potential preservative chemicals. Document no. IRG/WP 2113. The International Research group of Wood Preservation, Peebles

Candelier K, Chaouch M, Dumarçay S, Petrissans A, Petrissans M, Gérardin P (2011) Utilization of thermodesorption coupled to GC-MS to study stability of different wood species to thermodegradation. J Anal Appl Pyrol 92:376-383

Candelier K, Dumarçay S, Pétrissans A, Gérardin P, Pétrissans M (2013) Comparison of mechanical properties of heat treated beech woods cured under nitrogen or vacuum. Polym Degrad Stab 98:1762-1765

Candelier K, Thévenon MF, Pétrissans A, Dumarçay S, Gérardin P, Pétrissans M (2016) Control of wood thermal treatment and its effect on decay resistance: a review. Ann For Sci. doi:10.1007/ s13595-016-0541-x (In press)

Chaouch M, Pétrissans M, Pétrissans A, Gérardin P (2010) Use of wood elemental composition to predict heat treatment intensity and decay resistance of different softwood and hardwood species. Polym Degrad Stab 95:2255-2259

Chaouch M, Dumarçay S, Pétrissans A, Pétrissans M, Gérardin P (2013) Effect of heat treatment intensity on some conferred properties of different European softwood and hardwood species. Wood Sci Technol 47(4):663-673

Chen Y, Fan Y, Gao J, Stark NM (2012) The effect of heat treatment on the chemical and color change of black locust (Robinia pseudoacacia) wood flour. BioResources 7:1157-1170
CRIQ (2003) Forest products issued from 2nd transformation processes - Wood heat treatment [in French]. Report to the ministère des Ressources naturelles, de la Faune et des Parcs (MRNFP) by the Centre de recherche industrielle du Québec (CRIQ)

Curling S, Clausen C, Winandy J (2002) Relationships between mechanical properties, weight loss, and chemical composition of wood during incipient brown-rot decay. Forest Products Journal 52(7/8):3439

Dilik T, Hiziroglu S (2012) Bonding strength of heat treated compressed Eastern red cedar wood. Mater Des 42:317-320

Doi S, Takahashi M, Yoshimura T, Kubota M, Adachi A (1998) Attraction of steamed Japanese larch (Larix leptolepis (Sieb. et Zucc.) Gord.) heartwood to the subterranean termite Coptotermes formosanus Shiraki (Isoptera: Rhinotermitidae). Holzforschung 52: 7-12

Edlund ML, Jermer J (2004) Durability of heat-treated wood. COST Action E22 Environmental Optimisation of Wood Protection, Lisbon, Portugal, March, 22-23, 2004

Elaieb MT, Candelier K, Pétrissans A, Dumarçay S, Gérardin P, Pétrissans M (2015) Heat treatment of Tunisian soft wood species: Effect on the durability, chemical modifications and mechanical properties. Maderas, Cienc. tecnol, 17 (4), 699-710

EN 117 (2013) Wood preservatives - Determination of toxic values against Reticulitermes species (European termites) (Laboratory method). European Committee for Standardization (CEN), Brussels

EN 335 (2013) Durability of wood and wood-based products - Use classes: definitions, application to solid wood and wood-based products. European Committee for Standardization (CEN), Brussels

EN 350-1 (1994) Durability of wood and wood based products Natural durability of solid wood - Part 1: Guide to principles of testing and classification of the natural durability of wood. European Committee for Standardization (CEN), Brussels

EN 408 (2012) Timber structures - Structural timber and glued laminated timber - Determination of some physical and mechanical properties. European Committee for Standardization (CEN), Brussels

Esteves B, Pereira HM (2009) Wood modification by heat treatment: a review. BioResources 4(1):370-404

Fengel D, Wegener G (1989) Wood - Chemistry, Ultrastructure, Reactions. Berlin, Germany, Walter de Gruyter, Chapter 12 (Influence of Temperature): 319-344

Finnish ThermoWood Association (2003) Manuel ThermoWood. Snellmninkatu 13, FIN-00171 Helsinki, Finland

Hakkou M, Pétrissans M, Gérardin P, Zoulalian A (2006) Investigation of the reasons for fungal durability of heat treated beech wood. Polym Degrad Stab 91:393-397

Hannouz S (2014) Development of indicators for the mechanical characterization and durability of heat-treated wood [In French]. $\mathrm{PhD}$ Thesis, LaBoMaP, ENSAM-Arts et Métier ParisTech Cluny, France

Hannouz S, Collet R, Buteaud JC, Bléron L, Candelier K (2015) Mechanical characterization of heat treated ash wood in relation with structural timber standards. Pro Ligno 11(2):3-10

Hermoso E, Fernández-Golfín J, Conde M, Troya MT, Mateo R, Cabrero J, Conde M (2015) Characterization of thermally modified pinus radiata timber [In Spanish]. Maderas. Ciencia y tecnología 17(3):493-504

Hill CAS (2006) Wood modification: Chemical. Thermal and other processes, Wiley

Humar M, Bucar B, Pohleven F (2006) Correlation between modulus of elasticity, mass losses and FTIR spectra of copper treated decayed wood. Document No. IRG/WP 06-10580. The International Research Group on Wood Preservation, Tromsoe, Norway 
Inari G, Petrissans M, Lambert J, Ehrhardt JJ, Gerardin P (2007) Chemical reactivity of heat-treated wood. Wood Sci Technol 41:157-168

Jämsä S, Viitaniemi P (2001) Heat treatment of wood. Better durability without chemicals. In A.O. Rapp (Ed.), Review on heat treatments of wood. Proceedings of the Special Seminar on Heat Treatments, Antibes, France, 9 February 2001 (pp. 17-22). Luxembourg: Office for Official Publications of the European Communities

Junga U, Militz H (2005) Particularities in agar block tests of some modified woods caused by different protection and decay resistance. Proceedings of the 2nd European Conference on Wood Modification, Göttignen

Kamdem DP, Pizzi A, Jermannaud A (2002) Durability of heattreated wood. Holz Roh Werkst 60:1-6

Karamanoğlu M, Akyıldız MH (2013) Colour, gloss and hardness properties of heat treated wood exposed to accelerated weathering. Pro Ligno 9(4):729-738

Kim G, Yun K, Kim J (1998) Effect of heat treatment on the decay resistance and the bending properties of radiate pine sapwood. Material und Organismen 32(2):101-108

Korkut S, Korkut DS, Kocaefe D, Elustondo D, Bajraktari A, Çakıcıer $\mathrm{N}$ (2012) Effect of thermal modification on the properties of narrow-leaved ash and chestnut. Ind Crops Prod 35(1):287-294

Lekounougou S, Kocaefe D (2014) Effect of thermal modification temperature on the mechanical properties, dimensional stability, and biological durability of black spruce (Picea mariana). Wood Mat Sci Eng 9(2):59-66

Mazela B, Zakrzewski R, Grześkowiak W, Cofta G, Bartkowiak M (2004) Resistance of thermally modified wood to basidiomycetes. EJPAU, Wood Technol 7(1). http://www.ejpau. media.pl

Mburu F, Dumarçay S, Huber F, Pétrissans M, Gérardin P (2006) Improvement of Grevillea robusta durability using heat treatment. Document No. IRG/WP 06- 40333. The International Research Group on Wood Preservation, Tromsoe, Norway

Metsä-Kortelainen S, Viitanen U (2010) Effect of fungal exposure on the strength of thermally modified Norway spruce and Scots pine. Wood Mat Sci Eng 1:13-23

Metsä-Kortelainen S, Viitaniemi P (2009) Decay resistance of sapwood and heartwood of untreated and thermally modified Scots pine and Norway spruce compared with some other wood species. Wood Mat Sci Eng 4(3-4):105-114

Metsä-Kortelainen S, Anitikainen T, Viitaniemi P (2005) The water absorption of sapwood and heartwood of Scots pines and Norway spruce heat-treated at $170 \&$ \#xB0;C, $190 \&$ \#xB0;C, $210 \&$ \#xB0;C and 230 \& \#xB0;C. Holz Roh-Werkst. 64(3):192-197

Militz H (2002) Heat treatment of wood: European Processes and their background. Document No. IRG/WP 02- 40241. The International Research Group on Wood Preservation, Cardiff, Wales, United Kingdom

Momohara I, Ohmura W, Kato H, Kubojima Y (2003) Effect of hightemperature treatment on wood durability against the Brown-rot fungus, Fomitopsis palustris, and the termite, Coptotermes formosanus. In: International Iufro Wood Drying Conference. s.l. Proceedings... s.1., pp. 284-287

Nf, ISO 10390 International Organization for Standardization (2005) Soil quality - Determination of pH. AF.NOR, France

Nunes L, Nobre T, Rapp A (2004) Thermally modified wood in choice tests with subterranean termites. COST E37, Reinbeck

Paul W, Ohlmeyer M, Leithoff H (2006) Thermal modification of OSB-strands by a one-step heat pretreatment Influence of temperature on weight loss, hygroscopicity and improved resistance. Holz Roh- Werkst 65:57-63

Pétrissans M, Gérardin P, El Bakali I, Serraj M (2003) Wettability of heat-treated wood. Holzforschung 57(3):301-307
Pétrissans M, Pétrissans A, Gérardin P (2007) Check the durability of heat treated beech wood [In French]. Tracés, Bulletin technique Technologie du bois de la Suisse Romande 17:12-16

Råberg U, Geoffrey D, Terviez N (2012) Loss of strength in biologically degraded thermally modified wood. BioResources 7(4):4658-4671

Rousset P, Perré P, Girard P (2004) Modification of mass transfer properties in poplar wood (P. robusta) by thermal treatment at high temperature. Holz Roh-Werkst. 62 (2): 113-119

Sailer M, Rapp AO, Leithoff H, Peek RD (2000) Vergütung von Holz durch Anwendung einer Öl-Hitzebehandlung (Upgrading of wood by application of an oil-heat treatment) (in German). Holz Roh- Werkst 58:15-22

Salman S, Pétrissans A, Thévenon MF, Dumarçay S, Gérardin P (2016) Decay and termite resistance of pine blocks impregnated with different additives and subjected to heat treatment. Eur J Wood Prod 74(1):37-42

Sivonen H, Nuopponen M, Maunu SL, Sundholm F, Vuorinen T (2003) Carbonthirteen cross-polarization magic angle spinning nuclear magnetic resonance and fourier transform infrared studies of thermally modified wood exposed to brown and soft rot fungi. Appl Spectrosc 57:266-273

Sivrikaya H, Ekinci E, Can A, Tasdelen M, Gokmen K (2015a) Effect of heat treatment on the weathering and hardness properties of some wood species. Proceedings of the $11^{\text {th }}$ Meeting of the Northern European Network for Wood Sciences and Engineering (WSE), Poland

Sivrikaya H, Can A, Teresa de Troya MC (2015b) Comparative biological resistance of differently thermal modified wood species against decay fungi, reticulitermes grassei and hylotrupes bajulus. Maderas. Ciencia y tecnología 17(3):559-570

Sjöström E (1981) Fundamentals and Applications, in: Wood chemistry, Wood polysaccharides. Academic Press, New York (USA), Chapter 3: 49-67

Stamm AJ (1956) Thermal Degradation of Wood and Cellulose. Ind Eng Chem 48(3):413-417

Stamm AJ (1964) Wood and Cellulose Science. Roland Press, New York, pp 312-342

Surini T, Charrier F, Malvestio J, Charrier B, Moubarik A, Castéra P, Grelier S (2012) Physical properties and termite durability of maritime pine Pinus pinaster Ait., heat-treated under vacuum pressure. Wood Sci Technol 46(1):487-501

Šušteršic Ž, Mohareb A, Chaouch M, Pétrissans M, Petrič M, Gérardin P (2010) Prediction of decay resistance of heat treated wood on the basis of its elemental composition. Polym Degrad Stab 95:94-97

Syrjänen T, Kangas E (2000) Heat treated timber in Finland. Document No. IRG/WP/00-40158. The International Research Group on Wood Protection, Kona, Hawaii, USA

Talaei A, Karimi AN, Thévenon MF (2013) Influence of heat treatment medium on fungal resistance of beech wood. Document No. IRG/WP 13-40643. The International Research Group on Wood Protection, Stockholm, Sweden

Temiz A, Yildiz U (2006) The use of modulus of elasticity and modulus of rupture to assess wood decay in laboratory soilbed test. Document No. IRG/WP 06-20338. The International Research Group on Wood Preservation, Tromsoe, Norway

Tenorio C, Moya R (2013) Thermogravimetric characteristics, its relation with extractives and chemical properties and combustion characteristics of ten fast-growth species in Costa Rica. Thermochim Acta 563:12-21

Tjeerdsma BF, Stevens M, Militz H (2000) Durability aspects of hydrothermal treated wood. Document No. IRG/WP00-40160. The International Research Group on Wood Preservation, Kona Surf, Hawaii, USA 
Venäläinen M, Partanen H, Harju A (2014) The strength loss of Scots pine timber in an accelerated soil contact test. International Biodeterioration \& Biodegradation, 86 (B): 150-152

Viitanen H, Jämsä S, Paajanen L, Nurmi A, Viitaniemi P (1994) The Effect of Heat Treatment on the Properties of Spruce. Document No. IRG/WP 94-40032. The International Research Group on Wood Preservation, Nusa Dua, Bali, Indonesia

Weiland JJ, Guyonnet R (2003) Study of chemical modifications and fungi degradation of thermally modified wood using DRIFT spectroscopy. Holz Roh- Werkst 61:216-220

Welzbacher CR, Rapp OA (2002) Comparison of thermally modified wood originating from four industrial scale process - durability. Document No. IRG/WP 02-40229. The International Research Group on Wood Preservation, Cardiff, Wales, United Kingdom

Welzbacher CR, Rapp AO (2007) Durability of thermally modified timber from industrial- scale processes in different use classes: results from laboratory and field tests. Wood Mat Sci Eng 2:4-14
Welzbacher CR, Brischke C, Rapp AO (2007) Influence of treatment temperature and duration on selected biological, mechanical, physical and optical properties of thermally modified timber. Wood Material Sci Eng 2:66-76

XP CEN/TS 15083-1 (2006) Durability of wood and wood-based products - Determination of the natural durability of solid wood against wood destroying fungi - Test methods - Part 1: basidiomycetes. European Committee for Standardization (CEN), Brussels

XP CEN/TS 15083-2 (2006) Durability of wood and wood-based products - Determination of the natural durability of solid wood against wood destroying fungi - Test methods - Part 2: soft rotting micro-fungi. European Committee for Standardization (CEN), Brussels

Yalcin M, Sahin HI (2015) Changes in the chemical structure and decay resistance of heat-treated narrow-leaved ash wood. Maderas. Ciencia y tecnología 17(2):435-446 